\title{
Arachnoiditis and Chiari I malformation
}

\author{
Andreas K. Demetriades ${ }^{1,2}$ (ID
}

Received: 14 September 2020 / Accepted: 15 September 2020 / Published online: 18 September 2020

(C) Springer-Verlag GmbH Austria, part of Springer Nature 2020

A Chiari malformation is one of those conditions which continue to fascinate and perplex modern neurosurgeons and where a range of controversies continue for several decades. Debate continues even on the name of the condition and when it was first described, on its pathophysiology and on several aspects of surgical technique [1].

One such point of uncertainty is the role of arachnoiditis in Chiari I malformation. Is it a primary or secondary phenomenon? Or both? Evidence from colleagues with a long standing and demonstrable interest in this condition comes to shed some light on this. Both histological and intraoperative assessments of the arachnoid are reported in a series of 162 consecutive patients spanning the period of a decade (2006-2016) [2].

Klekamp and colleagues found that the arachnoid was thicker in adults than children and in secondary than primary decompressions. They also report, importantly, that histological classification correlated with preoperative symptoms, such as ataxia and motor or sensory deficit, as well as with postoperative outcomes both in the short and long term. These are significant results and do put on the map a histological-clinical correlation in the pathophysiology of this condition [2].

There are some important learning points worth mentioning. In a rare disease, where a randomised clinical trial has often been described as impractical, the approach of the reporting team has been methodical.

- They started an institutional database, with prospective collection, for all such cases in 1991.

- They have been since then recording their intraoperative observations of the arachnoid and its relationship with surrounding tissue.

This article is part of the Topical Collection on Neurosurgery general

Andreas K. Demetriades

demetriades@gmail.com

1 Department of Neurosurgery, Royal Infirmary of Edinburgh, Little France, Edinburgh EH16 4SA, UK

2 Edinburgh Spinal Surgery Outcome Studies Group, Edinburgh, UK
- And the clinical outcomes both preoperatively and postoperatively, at all points of contact in the follow-up period.

- Their surgical technique has remained largely consistent during this period.

This has enabled the long-term observation for 'progression-free survival', and though there is no control arm in their study, they report important observational data.

An association between arachnoiditis and Chiari malformation is not new. Reports exist of an acquired Chiari I even after distal tuberculous arachnoiditis in the lumbar spine, for example [5]. The conundrum of primary arachnoiditis, however, and its role in Chiari malformation remain unclear; the reported results are interesting [2]. The association between arachnoiditis and syringomyelia is equally well recognised, though poorly understood, and the current authors do discuss this association in their series [2-4].

Some believe that an arachnoid sparing decompression can minimise the risk of arachnoiditis, as opposed to arachnoid opening and shrinking of the tonsils $[6,7]$. This current series will not settle that debate or any debate on how foramen magnum decompression might best be performed, but the authors provide long-term results with progression-free rates exceeding $95 \%$ after 5 and 10 years for their technique, which has remained consistent. This provides a benchmark against which proponents of other techniques might wish to compare.

\section{Compliance with ethical standards}

Conflict of interest The author declares that he has no conflict of interest.

\section{References}

1. Frič R, Eide PK (2020) Chiari type 1-a malformation or a syndrome? A critical review. Acta Neurochir 162(7):1513-1525. https://doi.org/ 10.1007/s00701-019-04100-2

2. Heidary M, Respondedk M, Klekamp J (2020) Histological and intraoperative evaluations of the arachnoid in patients with Chiari I malformation. Acta Neurochir (in press) 
3. Holly LT, Batzdorf U (2019) Chiari malformation and syringomyelia. J Neurosurg Spine 31(5):619-628. https://doi.org/10.3171/2019. 7.SPINE181139

4. Klekamp J, Iaconetta G, Batzdorf U, Samii M (2002) Syringomyelia associated with foramen magnum arachnoiditis. J Neurosurg 97(3 Suppl):317-322. https://doi.org/10.3171/spi.2002.97.3.0317

5. Kondety SK, Chatterjee S (2016) Acquired Chiari malformation secondary to tuberculous arachnoiditis of the lumbar spine. Neurol India 64(5):1066-1068. https://doi.org/10.4103/0028-3886.190231

6. Perrini P, Benedetto N, Tenenbaum R, Di Lorenzo N (2007) Extraarachnoidal cranio-cervical decompression for syringomyelia associated with Chiari I malformation in adults: technique assessment.
Acta Neurochir 149(10):1015-1023. https://doi.org/10.1007/ s00701-007-1276-0

7. Vidal CHF, Brainer-Lima AM, Valença MM, Farias RL (2019) Chiari 1 Malformation surgery: comparing non-violation of the arachnoid versus arachnoid opening and thermocoagulation of the tonsils. World Neurosurg 121:e605-e613. https://doi.org/10.1016/j. wneu.2018.09.175

Publisher's note Springer Nature remains neutral with regard to jurisdictional claims in published maps and institutional affiliations. 